\title{
Asia-Pacific's responses to the Ukraine crisis: third-party alignment with sanctions on Russia
}

\section{Las respuestas desde Asia-Pacífico a la crisis de Ucrania: alineamiento de terceros con las sanciones a Rusia}

\section{Maria Shagina}

CEES Postdoctoral Fellow, Center for Eastern European Studies, University of Zurich. mariia.shagina@hist.uzh.ch

How to cite this article: Shagina, Maria. "Asia-Pacific's responses to the Ukraine crisis: third-party alignment with sanctions on Russia". Revista CIDOB d'Afers Internacionals, issue 125 (September 2020), p. 139-164. DOI: doi.org/10.24241/rcai.2020.125.2.139/en

\begin{abstract}
Since 2014 and Russia's annexation of Crimea and the start of hostilities in Donbas, the West has shown unprecedented solidarity in imposing sanctions on Russia. Yet Asia-Pacific's response to the Ukraine crisis has been different. While Japan and New Zealand imposed symbolic sanctions, South Korea refrained from introducing any measures at all. The main objective of this paper is to explore the response of the Asia-Pacific region to the Ukraine crisis and the underlying motivations behind these stances. From a perspective of sanctions coordination and alliance behaviour theory, this paper examines the interaction between domestic and international factors when states decide whether or not to join international sanctions coalitions.
\end{abstract}

Keywords: sanctions, Russia, Ukraine, Ukraine crisis, Asia-Pacific region
Resumen: Desde 2014, con la anexión de Crimea por parte de Rusia y el inicio de las hostilidades en el Donbás, Occidente ha demostrado una solidaridad sin precedentes en la imposición de sanciones a Rusia. No obstante, la respuesta de la región de Asia-Pacífico a la crisis de Ucrania ha sido diferente. Mientras que Japón y Nueva Zelanda aplicaron sanciones simbólicas, Corea del Sur se abstuvo de introducir medida alguna. El objetivo principal de este artículo es explorar la respuesta de la región de Asia-Pacífico a la crisis ucraniana y las motivaciones subyacentes tras este posicionamiento. Partiendo de la perspectiva de la teoría del comportamiento de las alianzas y coordinación de sanciones, este artículo examina la interacción entre los factores domésticos y los internacionales a la hora de determinar la decisión de los estados de (no) unirse a las coaliciones de sanciones internacionales.

Palabras clave: sanciones, Rusia, crisis de Ucrania, Asia-Pacífico 
Following Russia's annexation of Crimea and its incursion in eastern Ukraine in March 2014, the West condemned Russia's actions and imposed targeted sanctions. After the United Nations (UN) failed to impose multilateral sanctions, the US and EU introduced a range of closely-coordinated autonomous measures instead. As part of diplomatic measures, Russia was excluded from the G8, while the negotiations on visa liberalization were cancelled. The US and EU imposed individual sanctions - visa bans and asset freezes - on those who were deemed responsible for undermining Ukraine's sovereignty and territorial integrity. Following the downing of the Malaysian Airline Flight 17 (MH17) in July 2014, the West triggered hard-hitting economic sanctions, targeting the Russian energy, defence and financial sectors. The sectoral measures aimed to deny Russian banks, energy, and defense firms access to new securities, arms and dual-use goods, and advanced technology. The duration of the sanctions was linked to the fulfilment of the Minsk Agreement II ${ }^{\mathrm{I}}$. As the main architects of the sanctions regime, the US and EU sought to persuade other states to cooperate and join the Western sanctions coalition. Showing their commitment to the international norms, Albania, Australia, Canada, Georgia, Iceland, Japan, Lichtenstein, Moldova, Montenegro, New Zealand, Norway, Switzerland, and Ukraine joined. Collectively, it became "a global chorus of voices that are speaking in opposition to what Russia is doing to its Ukraine policy" (The American Presidency Project, 2014).

Since 2014, the international community has shown an unprecedented unanimity in the imposition and prolongation of the sanctions vis-à-vis Russia. Despite the diverging national interests and ranging economic dependencies on Russia, the aligned countries managed to converge their different voices into a united policy. Behind the scenes, however, the formulation of a sanctions policy in each country was far from a rubber-stamp formality and was subjected to a complex decision-making process. Tensions between autonomy and dependence - that is the tug-of-war between international pushing and domestic pulling factors - has shaped the countries' policy preferences.

For Asia-Pacific, the Ukraine crisis became a wake-up call and a reminder of the constantly shifting balance of power dynamics. Despite its geographical distance, the Russian-Ukrainian conflict threatened to upset the fragile

1. Editor's note: Minsk II was a political summit held in February 2015 where the leaders of Ukraine, Russia, France, and Germany agreed on a new package of measures meant to stop fighting in the Donbas. 
status quo in the region. It was feared that Russia's aggressive behaviour would embolden China's increasing assertiveness, while the US' indecisive response towards Russia raised the question of Washington's commitment to defend its Asian allies (Rolland, 2015). Seeking to maintain a delicate balancing act between great powers, the majority of the Asia-Pacific countries abstained from taking any sides. Following its traditional non-alignment policy, India abstained from joining Western sanctions. Similarly, the ASEAN countries did not follow suit. Affected by the tragedy of MH17, Australia is the only regional power that imposed a robust sanctions regime. Even China adopted a cautious position, abstaining from the UN vote on the condemnation of Russia's annexation of Crimea, but supporting Ukraine's territorial sovereignty.

The positions of Japan, South Korea and New Zealand are particularly puzzling. Although geographically the countries are placed in Asia-Pacific, politically they have been considered part of the West. Historically, all three have been responsive to the West's pressures and remained receptive to their calls for action. Due to their strategic security partnerships with the US and shared

For Asia-Pacific, the Ukraine crisis became a wake-up call and a reminder of the constantly shifting balance of power dynamics. Despite its geographical distance, the Russian-Ukrainian conflict threatened to upset the fragile status quo in the region. values with the West, Tokyo, Seoul and Wellington usually embarked on a bandwagoning strategy and followed its lead on foreign policy issues $(\mathrm{Bu}-$ chanan, 2010; Martin, 1992a; Snyder, 2018). However, when it came to Russian sanctions, the countries were reluctant to follow the US' and EU's suit. Despite the supposed low costs of sanctions due to their weak economic ties with Russia, Tokyo and Wellington only partially bandwagoned on the West's sanctions, while Seoul abstained from introducing any restrictive measures altogether. Such behaviour contradicts the standard argument in international relations theory which claims that in a conflict situation small and middle powers form alliances with larger states and bandwagon on their decisions (Walt, 1987) and opposes the standard assumption in sanctions theory which states that countries with weak economic relations towards a target are more inclined to adopt punitive measures as the costs of sanctions would be low for them (Biersteker and van Bergeijk, 2015).

Looking beyond the effectiveness of sanctions, this article focuses on the motivational structures of Japan, South Korea and New Zealand to (not) align with Western sanctions. It aims to examine why some states decide to cooperate, while others choose to defer. In particular, it seeks to shed light on a 
complex process of decision-making behind the decision to impose sanctions and on the interplay of domestic and external factors that shape the countries' foreign policy preferences. By understanding the motivations for their (non) alignment, this article seeks to provide an empirical perspective on the international relations debate regarding the mechanisms of cooperation and the effectiveness of sanctions.

\section{Alliance theory and sanctions cooperation}

This article focuses on the two strands of literature - the study of international cooperation and the study of international sanctions. Why states cooperate with each other and how they choose to form alliances has been the most important subject of research in international politics. The classic realism is pessimistic about international cooperation, as it posits that states are placed in the self-help anarchic international system. The fundamental goal of states is to ensure their survival, by seeking relative gains (Grieco, 1988; Mearsheimer, 1994). In such a zero-sum game, cooperation for mutual gains is "harder to achieve, more difficult to maintain" (Grieco, 1988: 302). Structural realism suggests that a state's behaviour is determined by structural power. In other words, the behaviour of international actors is defined by the distribution of aggregate capabilities in the international system. International politics is best explained through international system dynamics rather than through domestic politics. The balance-of-power theory, which is at the core of structural realism, contends that power imbalances force states to balance against an external enemy (Waltz, 1979). Geographical proximity to the threat, offensive capabilities and perceived intentions will increase the chances of states' balancing behaviour. Weak, isolated states, however, have little option but to bandwagon (Walt, 1987). Neoliberal institutionalism offers a different perspective on international cooperation. Drawing on structural realism, neoliberal institutionalism places an important focus on international institutions (Axelrod, 1985; Keohane, 1989). An actor's behaviour is regulated by the structure of international institutions, whereby the rules of institutions constitute the resource of power (Keohane, 1984). Asymmetrical information and high transactional costs are the main impediments for international cooperation. Therefore, institutions are considered the most effective way of solving the problem of free-riding and facilitate "mutually beneficial cooperation" (Axelrod and Keohane, 1985). 
Moving beyond the bipolar Cold War dynamics, the new theoretical and empirical literature sought to re-examine patterns of international cooperation in light of multipolarity. Firstly, instead of solely focusing on external power relationships, domestic factors were factored in in the analysis of alliance formation. Alignment behaviour is examined in conjunction with domestic processes, ideology and individual perceptions of statesmen (Barnett and Levy, 1991; Kaufman, 1992). Secondly, the balancing/bandwagoning dichotomy was widened to account for alternative behaviour patterns, including those derived from the collective action theory - chain-ganging (unconditional support of allies) and buck-passing (passing the costs for opposing an aggressor to others) (Christensen and Snyder, 1990; Posen, 1984; Schweller, 1994). Finally, the concepts of small and middle powers were introduced to refine the classic alliance theory. Historically focused on great powers, the dominant literature traditionally overlooked lesser powers for their assumed inability to influence international politics (cf. Mearsheimer, 1994). Viewed through the lenses of secondary players, the middle power theory offered a more nuanced picture of international politics, assigning greater weight to multilateralism, institution-building and consensus-seeking (Cooper et al., 1993; Beeson, 2011). In a similar vein, alliance shelter theory, developed to explain the motivations of small states, claimed that both international and domestic factors are equally important for small states when they seek political and economic shelter (Bailes et al., 2016: 13).

Several empirical studies on the nexus of alliance theory and sanctions alignment were conducted. In her pivotal study, Martin was the first one to combine sanctions theory and alliance behaviour theory, examining multilateral sanctions cooperation. Studying under which conditions states join economic sanctions, Martin established two crucial factors - the imposition of sanctions by international organisations and the willingness to incur costs by the primary sender states (Martin, 1992a). Applying a game-theoretic approach, Martin distinguished three different paths that can lead to cooperation: coincidence (states share common values and make their decisions independently from each other), coercion (the primary state persuades others to follow suit and uses issue linkage to induce changes), and co-adjustment (states make their decisions contingent on the preferences and actions of others) (ibid.: 31). Analysing the imposition of sanctions during the Falkland Islands conflict, Martin established that the UK's success in gaining cooperation from other states was linked to the institutional settings of the European Economic Community (EEC). Her findings revealed that the common interests were not sufficient enough to secure cooperation and the EEC played an important role in reducing transaction costs and making issue-linkage credible (ibid.: 145). 
Looking at sanctions as a two-level game, several scholars studied how the interplay of domestic factors and international bargaining influences the effectiveness of sanctions. Kaempfer and Lowenberg (1992) focused on the sender's domestic actors and their influence over the state's decision to impose economic coercion. They argued that interest groups can exert influence as to whether sanctions are introduced based on their economic reasons, while Simon (1996) added the political motives to the set of their reasoning. Analyzing the domestic politics in the target state, Morgan and Schwebach (1995) established that imposing high costs (relative to the issues at stake) on the politically powerful segments of society constitutes a part of the sanctions' success (Morgan and Schwebach, 1995: 261). Shifting the focus on the sender states, Drury (2000) examined the US presidents' decisions to impose sanctions. While the international fac-

Looking at sanctions as a two-level game, tors and the election cycle influenced several scholars studied how the interplay the presidents' decision to sanction of domestic factors and international bar- communist states, domestic poligaining influences the effectiveness of sanctions.

tics played little role while targeting Latin American states (ibid.: 35). Focusing on Japan's sanctions policy towards North Korea, Hughes examined the interaction between international systemic pressures and domestic processes in determining Tokyo's motivations. Hughes concluded that the formation of strong domestic coalitions shifted Japan's response vis-à-vis Pyongyang from a policy of engagement to a policy of containment, defying the pressures from international system (Hughes, 2006: 479). Examining small states behaviour, Thorhallsson and Gunnarsson (2017) studied Iceland's alignment with the US' and EU's sanctions against Russia. Under the pressure from domestic lobby affected by Russian countersanctions, Iceland withdrew from the EU declarations on sanctions, but continued to align with Western sanctions. By keeping a low profile, Reykjavik sought to navigate between international and domestic pressures (ibid.: 314).

\section{Methodology and case studies}

The originality of this article is threefold. First, in contrast to the majority of the studies on sanctions, it shifts the focus from the effectiveness to sanctions coordination and sanctions alignment. Instead of analysing a ready-made sanctions policy, this article examines the formation of the countries' sanctions policies and the interplay of domestic and external factors in shaping the sanctions 
design. Second, this article provides a comparative perspective and evaluates different decision-making mechanisms, resulting in various degrees of cooperation. Aiming to increase leverage, it compares the responses from multiple countries towards the Ukraine crisis. Finally, in contrast to the existing studies which primarily focus on positive cases of alignment (e.g. Hellquist, 2016; Thorhallsson and Gunnarsson, 2017), this article includes a negative case where alignment did not occur. In order to understand what hinders the imposition of sanctions, the inclusion of non-cooperative cases will enrich the understanding of international cooperation on economic sanctions.

To examine the motivations of Japan, South Korea and New Zealand (not) to align with Western sanctions on Russia over the Ukraine crisis, this article relies on three data sources - qualitative interviews in the selected cases, government documents, and media reports. Between January 2018 and August 2019, 20 semi-structured interviews were conducted with academics, policymakers and business representatives in Japan, South Korea and New Zealand. Employing cross-case comparative analysis, qualitative methods such as casestudy method and causal process-tracing were used.

\section{Co-adjustment game: the case of Japan}

The Ukraine crisis became one of the main challenges for the Shinzo Abe administration. On the one hand, Japan, as a G7 member, was expected to follow the international community in condemnation of Russia's wrongdoings in Ukraine. Highly valuing its G7 membership, Japan felt growing peer-pressure to join the Western sanctions coalition and was concerned about its outlying dovish position. On the other hand, with the Abe administration coming to power, Japan launched a policy of rapprochement and perceived Russia as a strategic partner in the region - both geopolitically and economically. Placed between a rock and a hard place, Japan opted for a co-adjustment policy, aimed at moderating its response to Russia. After the peer-pressure from other G7 members subsided, Tokyo embarked on a buck-passing strategy.

\section{Sanctions measures}

In comparison with the US and EU sanctions, Japan's measures were symbolic, diverging in scope and timing. Each batch of sanctions was introduced 
with a delay, indirectly pointing to the international pressure put on Tokyo ${ }^{2}$. Following the annexation of Crimea, Japan's Ministry of Foreign Affairs condemned Russia's aggression and its "attempt to change the status quo by force" (MOFA-Japan, 2014a). As part of its diplomatic measures, Japan suspended talks on easing visa restrictions, and froze agreements on new investments and an outer space cooperation. Russia's further involvement in the destabilization in eastern Ukraine forced Tokyo to introduce restrictive measures, banning entry for 23 Russian high officials. The visa bans, however, were not followed by asset freezes as it is commonly practiced. The blacklist was never disclosed and there are only speculations as to who have been targeted, considering a number of high-level Russian officials who visited Tokyo, including Sergey Naryshkin, Valery Gerasimov, Viktor Ozerov, and Igor Sechin - all of whom are on the US' or EU's sanctions lists. By non-disclosing the visa ban list, Japan spared Russian high officials and military involved in the annexation of Crimea and the destabilization in Donbas from public naming and shaming - the core objective of these measures.

The downing of MH17 in July 2014 triggered shockwaves through the international community. Both US and EU stepped up their measures sanctions regimes, by imposing impactful sectoral sanctions against Russia's energy, defence, and financial sectors. In contrast to the US and the EU, the downing of MH17 was not a game changer for Japan's sanctions policy. Initially, Japan limited its response to symbolic measures - Tokyo suspended the European Bank for Reconstruction and Development's financing of Russia's new projects and expanded visa bans for Russia-backed separatists in eastern Ukraine and self-proclaimed officials in Crimea. Pressured by the Obama administration, only in September 2014 did Japan follow the US' and EU's suit and added sectoral sanctions, including export restrictions on arms and dual-use goods, and prohibitions for new securities for five Russian banks - Sberbank, Vnesheconombank, Gazprombank, VTB, and Rosselkhozbank. Nevertheless, none of the Russian defence companies were targeted, while the energy sector was exempted altogether (MOFA-Japan, 2014b).

2. Implementation of 1) diplomatic sanctions: US and EU - on March 2014, Japan - on 18 March 2014; 2) restrictive measures: US and EU - on 16 and 17 March 2014 respectively, Japan - on 29 April 2014; 3) economic sanctions: US and EU - on 16 and 30 July 2014 respectively, Japan - on 24 September 2014. 
The timeline and the framing of Japan's sanctions provide important evidence of Tokyo's co-adjustment game. The institutional affiliation with the G7 shaped Japan's initial response to Russia, by allowing to co-adjust its measures in line with the others'. The G7 membership rendered crucial information about the actions of the others and allowed the Japanese government to calibrate the scope and strength of its measures. In particular, by delaying its sectoral sanctions, Tokyo could alleviate its concerns about the disproportionate sanctions costs and moderate its measures accordingly. Displaying riskaverse behaviour, Japan linked each round of sanctions to the G7 statements. Placing the emphasis on the G7, Japan distanced itself from the punitive measures and shifted the responsibility to the international level. In response, Russia signaled back that the message was well-understood: Russia's list of targeted Japanese individuals was also not released, while Japan was excluded from Russia's counter-sanctions introduced in August 2014 (Kitade, 2016: 3).

Gradually, as the peer-pressure from the G7 subsided, the Japanese government stopped playing an assurance game. Since December 2014, Japan abstained from updating its measures or introducing new sanctions. As other G7 members showed lackluster commitment to the enforcement of sanctions, Japan embarked on a buck-passing strategy. The poor commitment from other G7 members such as Italy and France weakened the assurance mechanism for Japan and increased the leeway for its non-alignment. Japan was no longer concerned about its outlying behaviour and instead of bandwagoning on the West's condemnation of Russia, it refrained from any direct criticism. Following Russia's purported attempt to murder a former Russian spy, Sergei Skripal, and his daughter, Yulia, in the UK in March 2018, Japan opted to not support the British government in condemning the incident, claiming that there was a lack of evidence of Russian involvement (Brown, 2018). On other occasions, Tokyo did not provide direct support for airstrikes on the Russia-backed regime of Bashar Assad in Syria, and it also remained silent amid the Netherlands' and Australia's calls to hold Russia legally responsible for shooting down MH17 (Japan Times, 2018).

\section{Explanation}

Japan's symbolic sanctions reveal the country's strategic interests and reflect the geopolitical dynamics in Asia-Pacific. The geographical distance from the Ukraine crisis and low economic dependence on Russia only superficially explain Japan's lukewarm response. The rapprochement with Russia 
was perceived as the resolve to Japan's geopolitical concerns - the territorial dispute with Russia, China's rising economic power, and the North Korean crisis.

Firstly, Japan's soft response to Russia was triggered by the Abe administration's desire to re-open the dialogue in the hope of solving the territorial dispute over the Kuril Islands (the Northern Territories in Japanese) which has lasted over 70 years. In 1945, the Soviet Union occupied a group of islands off the coast of Hokkaido and since then Japan has been trying to reclaim them. After the failed negotiations in 2001, it was Shinzo Abe's personal devotion to re-start the dialogue and achieve the resolution within his term. Launched in 2013, the negotiations came to a halt after the annexation of Crimea. The Ukraine crisis came at a bad time for the Abe administration, as it jeopardized

Japan's symbolic sanctions reveal the country's strategic interests and reflect the geopolitical dynamics in Asia-Pacific. The geographical distance from the Ukraine crisis and low economic dependence on Russia only superficially explain Japan's lukewarm response.

to derail the nascent rapprochement between Tokyo and Moscow. From Tokyo's point of view, any irritations for Moscow had to be avoided and strong sanctions could ruin this unique historical opportunity of settling the territorial issue (Shagina, 2018: 4). By imposing symbolic sanctions, the Abe administration signaled to the Kremlin its unwillingness and reluctance to follow its Western allies. After the Ukraine crisis, Japan sought to rekindle its strategic partnership with Russia by re-launching the " $2+2$ " programme between foreign and defence ministries and by initiating an eight-point economic cooperation plan. Through Tokyo's lens, Russia was not seen as a threat and despite its wrongdoings in Ukraine was perceived as having no revisionist intentions in the region ${ }^{3}$.

Secondly, China's growing economic rise and its assertive behaviour in the region influenced Japan's decision to design weak Russian sanctions. Japan's reluctance to impose harsh measures was driven by the desire to avoid Russia's international alienation and to prevent the emergence of a strong Sino-Russian axis. Accelerated by the geopolitical rift with the West, Russia's relations with China quickly intensified, altering the status quo in the region. China became Russia's main alternative to the Western capital, investments, and advanced

3. Interview with an expert on Japan-Russia relations, Temple University, February 2018. 
technology. Moscow's reinforced pivot to Beijing made Tokyo concerned that it would be "sandwiched between the 'bear' to the north and the 'dragon' to the south" (Taniguchi and Bob, 2016). By imposing weaker sanctions, Japan's strategic goal was to signal to Russia that it could be an alternative regional partner to China. Showing its commitment to economic cooperation, Japan tried to at least "neutralize" Russia vis-à-vis China and to balance its geopolitical position in the region. ${ }^{4}$ On the other hand, by imposing autonomous sanctions on Russia, Japan was sending a clear message of deterrence to China. Japan feared that Russia's annexation of Crimea could embolden China to act more assertively in the disputed Senkaku (Diaoyu) Islands in the South China Sea. From Japan's point of view, NATO's unsatisfactory response to Russia's military aggression in Ukraine could serve as a historical precedent for an increasingly assertive China to change the status quo by force. Drawing strategic parallels, the Abe administration linked the stability in Eastern and Central Europe to the stability in Asia-Pacific: if the security norms get weakened in Eastern Europe, it indirectly puts at risk the security norms in the Asia-Pacific region (Bacon and Burton, 2017: 45).

Finally, the North Korean nuclear and missile threat - the second security threat after China - adds to Japan's cautious response to Russia's wrongdoings in Ukraine. With Russia's involvement, Japan hoped to cater to Moscow's long-standing interests to become a valuable dialogue partner and an

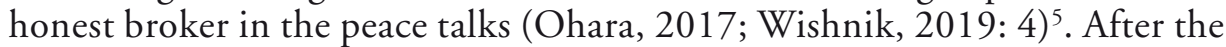
relations between Beijing and Pyongyang deteriorated and China backed the US-initiated sanctions at the UN Security Council, North Korea gradually turned to Russia (Toloraya, 2014; Lukin, 2019). Being aware of Moscow's limitations to achieve the resolve, Japan's rationale was to satisfy Russia's desire to demonstrate its global relevance and to affirm its great-power status, by allowing it to exercise its diplomatic acumen. In March 2018, Taro Kono and Sergey Lavrov, Japan's and Russia's Foreign Ministers, conducted a series of " $2+2$ " meetings to discuss the denuclearization of North Korea (Nikkei Asian Review, 2018).

4. Interview with an expert on Japan-Russia relations, University of Hokkaido, January 2018.

5. Interviews with experts on Japan-Russia relations, Kyushu University and the National Institute for Defense Studies, January and April 2018. 


\section{Limited bandwagoning: the case of New Zealand}

The New Zealand case illustrates episodes of limited bandwagoning and coercion. Despite the external pressure from the US and the UK, Wellington only partially aligned with Western sanctions against Russia. New Zealand's commitment to multilateralism and market-oriented economy explains the state's muted response. The coercion proved to be more effective after the EU linked the support for sanctions to bilateral trade negotiations. Although the issue linkage employed by Brussels did not lead to the imposition of sectoral sanctions by Wellington, it created favourable conditions for maintaining the status quo between New Zealand and Russia.

\section{Sanctions measures}

Despite being part of the Western alliance, Wellington defied external pressures from Washington and London. New Zealand was the latest among Western states to join the condemnation of Russia's breach of Ukraine's sovereignty and territorial integrity. After coordination with other countries, New Zealand limited its response to travel bans, leaving asset freezes out of the brackets. The list is believed to target roughly 20-30 Ukrainian and Russian state officials; however, similar to the Japanese case, it remains undisclosed to the public (Small, 2014). Murray McCully, the then Foreign Affairs Minister, admitted that the sanctions were largely symbolic: "these travel sanctions are a modest and careful step designed to recognise the significance of the situation but leave room for further diplomatic work to take place" (Young, 2014). Later, Wellington considered joining Western sectoral sanctions but abstained from them in the end. The government, however, asked businesses not to exploit the loopholes in the sanctions regimes and to limit trade with Russia (Trevett, 2014). Despite the country's official nonalignment with sectoral measures, New Zealand's banking institutions de facto sided with Western financial sanctions. As the majority of New Zealand banks represented subsidiaries of Australian banks, the former had to comply with Canberra's financial measures. As a result, all correspondent banks of sanctioned Sberbank, VEB, and VTB were closed, forcing the Russian banks to use intermediaries and conduct the transactions in local currencies (Kiselova and Kovaleva, 2014). 
Wellington's diverging behaviour was even more perplexing after the Skripal nerve agent attack. In a striking contrast to the 26-nation coalition, New Zealand refused to show solidarity and expel Russian diplomats in a symbolic gesture. Wellington's decision was made in defiance of the direct request from the UK government, its long-standing ally. Explaining the state's position, Prime Minister Jacinda Ardern claimed that there are "no undeclared Russian intelligence operatives" (Buchanan, 2018). As a small power, New Zealand was anticipated to opt for a conflict-averse approach and bandwagon with its close allies in times of international disputes (ibid., 2010: 256). As a member of the Commonwealth, of the Five Eyes intelligence sharing network ${ }^{6}$ and an extra-regional NATO and EU associate, it was expected from Wellington to toe the line of its allies, making Wellington's disobedience to satisfy the UK's demands rather surprising (ibid., 2018).

\section{Explanation}

The reasons for New Zealand's New Zealand's trade-dependent and export-oriented economy adds to its dovish position on Russia. Wellington had to perform a delicate balancing act between its commitments to international norms and its dependence on trade.

limited bandwagoning and the employment of symbolic sanctions are enshrined in the realm of domestic politics. Since the post-Cold War period, New Zealand has gradually started to recognise the collision of its shared identity with that of the West and the "limits to the cost it was prepared to pay for being part of the Western alliance" (Capie and McGhie, 2005: 237). As a small state, Wellington has been relying on the international institutions and diversified economic partners to offset its vulnerabilities stemming from its small power status. From Wellington's point of view, its commitment to multilateralism and market-oriented economy operated as a security shield from great-power rivalry (Buchanan, 2010: 265).

Without the UN multilateral sanctions, New Zealand showed only lukewarm support of unilateral measures against Russia and was not keen on authorization of sanctions outside of international institutions (Patnam, 2018: 99). Having joined the UN Security Council in 2015, New Zealand positioned itself

6. Editor's note: The Five Eyes (FVEY) is an intelligence alliance comprising Australia, Canada, New Zealand, the United Kingdom and the United States. 
more critically towards Russia, particularly towards its actions in Syria. Campaigning on the pledge to address the security challenges in Syria, New Zealand condemned "Russia's destructive role in the Syrian conflict" and pushed for a draft resolution to end all the attacks that may result in civilian casualties (New Zealand Foreign Affairs and Trade, 2016). After Russia vetoed the resolution, Gerard van Bohemen, New Zealand's representative at the UN, criticised Russia's actions (Stuff, 2016). Although Moscow initially excluded Wellington from its agricultural ban, in early 2017 this criticism triggered the introduction of a temporary ban on New Zealand's beef and beef products due to the detected feed addictive ractopamine in some samples (Hutching, 2017). In a classic move, Russia used the pretext of unsatisfactory sanitary standards to introduce non-tariff barriers in order to send a political signal to Wellington.

New Zealand's trade-dependent and export-oriented economy adds to its dovish position on Russia. Wellington had to perform a delicate balancing act between its commitments to international norms and its dependence on trade. As a small state, New Zealand had to compensate for its domestic vulnerabilities in terms of smallness of its market size and dependence on exports. New Zealand often adopted a pragmatic approach, by favouring commercial interests over security concerns and human rights issues (Buchanan, 2010: 273). In the past, the country continued to trade with the Soviet Union due to the strong agricultural lobby which was against trade disruptions over political issues (Dibb, 1985: 73). Prior to the Ukraine crisis, New Zealand and Russia-led Customs Union (currently the Eurasian Economic Union, EAEU) had been negotiating a free trade agreement (FTA) for four years. The agreement was supposed to boost the bilateral relationship due to the compatibility of their economies: Russia represents the world's second largest importer of dairy products, while New Zealand belongs to the world's largest exporter of dairy products. Although the economic benefits of the deal seemed to be modest for New Zealand, a strong lobby of the agricultural industry saw new market opportunities. Conversely, for Russia, the agreement offered more than just economic benefits. Signing the FTA with New Zealand promised to give the Russia-spearheaded EAEU prestige and credibility as an important international organization ${ }^{7}$. Designed as a "pilot project", the FTA agreement with New Zealand was planned to be used as a template for other Asia-Pacific countries (Headley, 2019: 216-217). How-

7. Interview with expert on New Zealand-Russia relations, University of Otago, August 2019. 
ever, in the aftermath of the Ukraine crisis, the New Zealand government was forced to suspend the talks and postpone the finalisation of the FTA. Since 2014, their bilateral relations have been effectively frozen.

In 2016, a reset of cooperation between New Zealand and Russia appeared in sight. Moscow expressed "an interest in restoring full-fledged cooperation", while Wellington saw the potential in concluding the FTA in its refreshed trade strategy (Kostyuk, 2016; NZ Herald, 2017). In 2016, New Zealand's divergent position on Russia drew international attention, when it was revealed that New Zealand First party included the reopening of negotiations with Russia as part of its coalition agreement's priorities (Nippert, 2017). Winston Peters, a party leader of the populist New Zealand First, has been known for his pro-Russian views. In the past, he strongly criticized Russian sanctions as being detrimental to the state's economy, as well as openly questioning Russia's involvement in the shooting down of MH17 and in the meddling in the US elections in 2016 (NZP, 2016; Trevett, 2018). New Zealand's intention to increase The economic pragmatism eventually prevailed - in contrast to a modest trade turnover between Russia and New Zealand, the overall trade between the EU and New Zealand amounted to NZ\$20 billion in 2016. The EU's issue linkage proved to be effective.

trade with Russia was perceived as

breaking ranks with the international community and sparked an outright criticism from the European Union. The EU ambassador Bernard Savage warned that the reactivation of the deal with Russia would complicate the negotiations over the FTA deal with Brussels (Nippert, 2017). The economic pragmatism eventually prevailed - in contrast to a modest trade turnover between Russia and New Zealand, the overall trade between the EU and New Zealand amounted to NZ\$20 billion in 2016 (Headley, 2019: 218). The EU's issue linkage proved to be effective, as Prime Minister Jacinda Ardern assured that a trade deal with the EU - not the one with Russia - was the state's top priority and guaranteed that the deal with Russia will not be finalised as long as the sanctions are in place.

\section{Hedging game: the case of South Korea}

The reasons of South Korea's non-alignment lie in the changing geopolitical dynamics in the region. Seoul's positioning on the Ukraine crisis is a sec- 
ond-order effect stemming from the intensifying great power rivalry between the US - China and the US - Russia. Abstaining from taking any sides, South Korea opted for a hedging strategy.

\section{Sanctions measures}

Despite its strategic security alliance with the US, South Korea did not align with the West on Russian sanctions. Seoul's reaction to Russia's wrongdoings in Ukraine was largely limited to the condemnation of Moscow's annexation of Crimea. In the media, the Ukraine crisis was scarcely covered, since it was geographically distant and thus had no immediate urgency for the Korean peninsula (Lankov, 2014). As the US and EU expanded their sanctions' package after the downing of MH17, the Korean government did not join. Following the West's suit to boycott Russian events, then the South Korean president Park Geun-hye did not participate in the opening of Winter Olympics in Sochi in 2014 and declined the invitation to attend the May $9^{\text {th }}$ parade in 2015 (Toloraya, 2014; Golunov, 2016). Unlike Japan, South Korea withstood pressure from the US to align and abstained from imposing any restrictive measures on Russia (Wong and Taylor, 2014). In contrast to Tokyo, Washington took a seemingly lighter approach with Seoul (Hess, 2016). The sense of immediate pressure on South Korea was absent, as the US recognized the priority of a more imminent threat on Seoul's agenda - the North Korean missile and nuclear crisis. As a non-G7 member state, South Korea's non-alignment was kept as a low-profile case and was not subjected to much external pressure to join Western measures.

\section{Explanation}

The geopolitical environment has been a long-standing factor for defining South Korea's foreign policy, with domestic factors playing rather a secondary role. To understand why Seoul decided to abstain from the imposition of Russian sanctions, it is important to comprehend the positions of great powers on North Korea and what role Russia was designed to play in South Korea's foreign policy. In the past, South Korea usually acted in lockstep with the US, its security ally. However, the unpredictability of Trump's administration, China's increasingly assertive behavior and North Korea's new missile tests have changed the fundamentals of regional dynamics (Pardo, 2018a). 
Employing middle power diplomacy, South Korea sought Russia's engagement to diminish its vulnerability to external threats. In 2013, President Park launched the Eurasian Initiative to foster economic collaboration and to contribute to trust- and peace-building in Northeast Asia. The objectives of the initiative were threefold: to launch multilateral economic cooperation on the peninsula in non-conventional security areas such as transport, energy and trade networks; to pursue the process of inter-Korean unification; and to offset the problem of "dual reliance" on the US and China (Taehwan, 2015). For all three objectives, Moscow was crucial in Seoul's initiative of peace and prosperity in Northeast Asia (Wishnick, 2019: 10). Energy cooperation was particularly important and the Russo-Korean gas pipeline involving North Korea was the key project for the realization of the Eurasian Initiative. The main assumption was that by establishing a habit of mutual cooperation in less politicised areas, it will be easier to compromise on highly sensitive security issues (Lee et al., 2014: 56). The initiative also aimed to resolve the dependence problem on the US and China. While politically the

To understand why Seoul decided to abstain from the imposition of Russian sanctions, it is important to comprehend the positions of great powers on North Korea and what role Russia was designed to play in South Korea's foreign policy.

alliance with the US has historically been the backbone of Seoul's security, economically China has become the country's largest trading partner. With the US-China relations deteriorating, balancing between the two great powers became more complicated for South Korea. Posed with a strategic dilemma, Seoul opted for an additional partner in the region - Russia.

Similar to the previous cases, the Ukraine crisis came at a bad time for South Korea. ${ }^{8}$ It threatened to undermine the full-scale launch of Park's renewed Nordpolitik, jeopardizing the efforts of normalization of inter-Korean relations. Russia's annexation of Crimea upset the balance of power dynamics and triggered far-reaching implications for the region. On the one hand, it raised the importance of nuclear weapons for North Korea, demonstrating to Pyongyang that international security guarantees are unreliable (Toloraya, 2014). On the other hand, the deterioration of relations with the West pushed Russia to accelerate its pivot to Asia. Moscow forged a strategic partnership with China, while intensifying its ties with North Korea. Particularly after

8. Interview with expert on security studies, the Sejong Institute, May 2019. 
Western sanctions on Russia, Moscow showed solidarity vis-à-vis its sanctioned partner: the overwhelming majority of North Korea's debt was written off, ambitious infrastructure investment deals were signed, while Moscow showed lapses in compliance with the UN sanctions. The increasing North Korea-Russia economic cooperation looked particularly conducive to South Korea's framework of the Eurasian initiative (Taehwan, 2015). In this situation, Seoul back-pedaled the introduction of any sanctions, as it feared that Russia could potentially derail its Nordpolitik in retaliation (The Asan Forum, 2014).

In the post-Crimea period, the new administration of President Moon Jaein (2017-) continued its non-alignment sanctions policy and the policy of rapprochement with Russia. ${ }^{9}$ Unveiled at Russia's Eastern Economic Forum in 2017, Moon's New Northern policy focused on multilateral economic cooperation on the Korean peninsula, by delinking the issue of denuclearization and inducing changes within the Kim Jong-Un regime (Snyder, 2018). As part of the New Northern Policy, the Nine-Bridges initiative was launched to pursue joint projects with Russia in such areas as energy, Arctic shipping routes, shipbuilding, and transportation. From Seoul's point of view, the policy aimed to strengthen economic relations between regional partners to promote peace and prosperity in the region (Pardo, 2018b). So far, South Korea's rapprochement to Russia has failed to achieved any progress on the normalization of inter-Korean relations, while Seoul's deployment of the US Terminal High Altitude Area Defense system only deepened Moscow's mistrust (Golunov, 2016).

\section{Conclusions}

Despite their strong ties with the West, Japan, New Zealand and South Korea were reticent to impose strong sanctions over Russia's wrongdoings in Ukraine. Surprisingly, the Western allies in Asia opted for a measured alignment, showing different degrees of cooperation. While Japan and New Zealand bandwagoned only in a limited scope, South Korea managed to abstain from any measures altogether. The motivational structures in each case revealed that

9. Interview with expert on the South Korean affairs, the Sino-NK research, May 2019. 
a combination of domestic factors and international pressures influenced the countries' sanctions policy. Despite its aggression in Ukraine, Russia was not viewed as a threat in the region and was treated as a security partner against an assertive China. This geopolitical dynamic was projected on the domestic level, where Russia was perceived as part of the regional security structure. In this situation, the imposition of Russian sanctions was considered detrimental to the countries' domestic strategies of engaging - not isolating - Moscow. In each case, the shifting geopolitical dynamics influenced the countries' moderate response to Russia, while the internal processes proved to be powerful enough to push back against external pressures. Personal commitments of individual politicians shaped the countries' foreign policy responses. Overall, the findings of this article strongly concur with the earlier statements on the necessity to analyse alliance behaviour from a three-level perspective - "the system, domestic politics and the perceptions of individual statesmen" (Kaufman, 1992: 439).

The three cases demonstrated that the classic realist argument in international relations that small and middle powers bandwagon on

Despite their strong ties with the West, Japan, New Zealand and South Korea were reticent to impose strong sanctions over Russia's wrongdoings in Ukraine. Surprisingly, the Western allies in Asia opted for a measured alignment, showing different degrees of cooperation.

the decisions of greater powers is not always true. In the situation of intensified great power confrontation, Japan, South Korea and New Zealand opted for a muted response, navigating between the desire for autonomy and the need for alliance. The cases illustrated that the precise nature of relationships between small/middle and great powers is not predetermined and is subject to domestic factors. In line with the recent literature on middle powers behaviour, this article showed that Japan and South Korea had the potential to exercise their independent agency and gain the room for maneuver. In line with the expectations of small powers' alliance behaviour, the New Zealand case provided further evidence to the established literature that small states prefer a strategy of nonalignment over any alternative in a situation of a great power confrontation and opt to bandwagon if a coercion mechanism is applied.

Drawing conclusions from each case, several implications for the studies of international cooperation and international sanctions can be made. First, international institutions proved to be crucial for facilitating international cooperation and contributing to sanctions unity. In line with neoliberal international relations theories, this article provides further evidence for the 
important role of institutions in creating positive contagion, preventing freeriding in the collective-action problems and increasing the degree of bandwagoning (Axelrod, 1985; Keohane, 1984; Martin, 1992a). It opposes the realist paradigm that claims that the role of institutions is marginalized due to the rationalist nature of states (Grieco, 1990). As the cross-case comparison between Japan and South Korea illustrated, the institutional embeddedness in the G7 proved to be vital for Japan's decision to join Western sanctions. It provided the necessary assurances and symmetrical information about the preferences of others. The institutional frameworks mitigated the fear of isolation, reduced the transaction costs for joining Western sanctions and elevated peer-pressure on the would-be defector Tokyo. Secondly, the case of New Zealand demonstrated that the issue linkage was important for the primary states to ensure the successful cooperation of third parties. The linkage functioned as a powerful lever and a conditionality mechanism to gain cooperation of uncooperative states. Finally, the analysed cases underlined the importance of sanctions coordination. Only by working in unison, can the sanctioning countries send a powerful message of deterrence. Without a well-coordinated sanctions response third parties often engage in free-riding or buck-passing, undermining the effectiveness of sanctions.

\section{Bibliographical references}

Axelrod, Robert. The Evolution of Cooperation. New York: Basic Books, 1985. Axelrod, Robert and Keohane, Robert O.. "Achieving Cooperation under Anarchy: Strategies and Institutions". World Politics, vol. 38, issue 1 (1985), pp. 226-254.

Bacon, Paul y Burton, Joe . "NATO-Japan Relations: Projecting Strategic Narratives of 'Natural Partnership' and Cooperative Security”. Asian Security, vol. 14, issue 1 (2017), pp. 38-50.

Bailes, Alyson J. K.; Thayer, Bradley A. y Thorhallsson, Baldur. "Alliance theory and alliance 'Shelter': the complexities of small state alliance behaviour". Third World Thematics: A TWQ Journal, vol. 1, issue 1 (2016), pp. 9-26.

Barnett, Michael N. and Levy, Jack S. "Domestic sources of alliances and alignments: the case of Egypt, 1962-73". International Organisations, vol. 45, issue 3 (1991), pp. 369-395.

Beeson, Mark. "Can Australia save the world? The limits and possibilities of middle power diplomacy". Australian Journal of International Affairs, vol. 65, issue 5 (2011), pp. 563-577. 
Biersteker, Thomas y van der Bergeijk, Peter A. G. (2015). "How and When Do Sanctions Work? Evidence". In Iana Dreyer and José Luengo-Cabrera (eds.). On Target? EU sanctions as security policy tools, ISSUE Report nr. 25. Paris: EU Institute for Security Studies, pp. 17-28.

Brown, James. "Japan and the Skripal poisoning: The U.K.'s fair-weather friend". The Japan Times, (27 March 2018) (online) https://www.japantimes.co.jp/opinion/2018/03/27/commentary/japan-commentary/japanskripal-poisoning-u-k-s-fair-weather-friend/.

Buchanan, Paul G.. "Lilliputian in Fluid Times: New Zealand Foreign Policy After the Cold War". Political Science Quarterly, vol. 125, issue 2 (2010), pp. 255-279.

Buchanan, Paul G. "New Zealand's claim it has no Russian spies is perplexing. Why is it isolating itself?" The Guardian, (28 March 2018) (online) https:// www.theguardian.com/world/2018/mar/28/new-zealands-claim-it-has-norussian-spies-is-perplexing-why-is-it-isolating-itself

Capie, David y McGhie, Gerald. "Representing New Zealand: Identity, Diplomacy and the Making of Foreign Policy". In: H. Liu, James; McCreanor, Tim; McIntosh, Tracey and Teaiwa, Teresia (eds.). New Zealand Identities: Departures and Destinations, Wellington: Victoria University Press, 2005, pp. 230-241.

Christensen, Thomas J. and Snyder, Jack. "Chain Gangs and Passed Bucks: Predicting Alliance Patterns in Multipolarity". International Organization, vol. 44, issue 2 (1990), pp. 137-168.

Cooper, Andrew F.; Higgott; Richard A. y Nossal, Kim R. Relocating MiddlePowers: Australia, Canada and the Changing World Order. Vancouver: University of British Columbia Press, 1993.

Dibb, Paul. "Soviet strategy towards Australia, New Zealand and the South West Pacific". Australian Outlook, vol. 39, issue 2 (1985), pp. 69-76.

Drury, Cooper. "How and Whom the US President Sanctions: A Time-series Cross-section Analysis of US Sanctions Decisions and Characteristics". In: Steve Chan and A. Cooper Drury (eds.). Sanctions as Economic Statecraft. Theory and Practice. Basingstoke: Palgrave Macmillan, 2000, pp. 17-36.

Grieco, Joseph M. "Anarchy and the Limits of Cooperation: A Realist Critique of the Newest Liberal Institutionalism". International Organization, vol. 42, issue 3 (1988), pp. 485-507.

Grieco, Joseph M. Cooperation among Nations: Europe, America, and NonTariff Barriers to Trade. Ithaca: Cornell University Press, 1990.

Golunov, Serghey. "Russia’s Korean Policy since 2012: New Hopes, Achievements, and Disappointments". The Asan Forum, (3 August 2016) (online) http://www.theasanforum.org/russias-korean-policy-since-2012-newhopes-achievements-and-disappointments/ 
Headley, James. Russia resurgent: The implications for New Zealand. In: A.M. Brady (ed.). Small states and the changing global order: New Zealand faces the future, Cham, Switzerland: Springer, 2019, pp. 213-229.

Hellquist, Elin. "Either with us or against us? Third-country alignment with EU sanctions against Russia/Ukraine". Cambridge Review of International Affairs, vol. 29, issue 3 (2016), pp. 997-1.021.

Hess, Maximilian. "Does it matter that South Korea has not imposed sanctions on Russia?”. Intersection, (17 May 2016) (online) http://intersectionproject.eu/node/436/pdf

Hughes, Christopher W. "The Political Economy of Japanese Sanctions Towards North Korea: Domestic Coalitions and International Systemic Pressures". Pacific Affairs, vol. 79, issue 3 (2006), pp. 455-481.

Hutching, Gerard. "Russian 'sabre rattling' over threat to ban New Zealand beef imports from February”. Stuff, (3 February 2017) (online) https:// www.stuff.co.nz/business/farming/89049136/russia-to-ban-new-zealandbeef-imports-from-february

Kaempfer, William H. y Lowenberg, Anton D. "Using threshold models to explain international relations". Public Choice, vol. 73 (1992), pp. 419-443.

Kaempfer, William H. y Lowenberg, Anton D. "A Public Choice Analysis of the Political Economy of International Sanctions". In: Chan, Steve and Drury, A. Cooper (eds.). Sanctions as Economic Statecraft. Theory and Practice. Basingstoke: Palgrave Macmillan, 2000, pp. 158-186.

Kaufmann, Robert G. 'To Balance or To Bandwagon?' Alignment Decisions in 1930s Europe”. Security Studies, vol. 1, issue 3 (1992), pp. 417-447.

Keohane, Robert O. After Hegemony. Cooperation and Discord in the World Political Economy, New Jersey: Princeton University Press, 1984.

Keohane, Robert O. International institutions and state power: Essays in international relations theory. Boulder: Westview Press, 1989.

Kiselova, Elena and Kovaleva, Elena. "Gosbanki otkluchili ot Novoi Zelandii" [National banks are disconnected from New Zealand], Kommersant, (27 November 2014) (online) https://www.kommersant.ru/doc/2619735

Kitade, Daisuke. "Considering the Effects of Japanese Sanctions Against Russia". Mitsui Global Strategic Studies Institute Monthly Report, (July 2016).

Kostyuk, Rusian. "Russia and New Zealand on a way to a reset". Russia Direct, (23 August 2016) (online) https://russia-direct.org/analysis/russia-andnew-zealand-way-reset

Lankov, Andrey. "Pochemu Yuzhnaia Koreia ne vveela sanktsii protiv Rossii". Republic, (8 September 2014) (online) https://republic.ru/posts/l/1153950 Lee, Kihyun; Kim, Jangho y Jae, Sunghoon. "Geopolitics of the Russo-Korean Gas Pipeline Project and Energy Cooperation in Northeast Asia”. Korea 
Institute for National Unification (May 2014).

Lukin, Artyom. "Russia’s Game on the Korea peninsula: Accepting China's Rise to regional Hegemony?". In: Choo, Jaewoo; Kim, Youngjun; Lukin, Artyom and Wishnick, Elizabeth (eds.). The China-Russia Entente and the Korean Peninsula, NBR Special Report nr. 78 (2019), pp. 21-29.

Martin, Lisa. Coercive cooperation: explaining multilateral economic sanctions. Princeton, New Jersey: Princeton University Press, 1992a.

Martin, Lisa. "Institutions and Cooperation: Sanctions during the Falkland Islands Conflict". International Security, vol. 16, issue 4 (1992b), pp. 143178.

Mearsheimer, John J. "The False Promise of International Institutions". International Security, vol. 19, issue 3 (1994), pp. 5-49.

MOFA-Japan (Ministry of Foreign Affairs of Japan). "Statement by the Minister of Foreign Affairs of Japan on the Measures against Russia over the Crimea referendum", (18 March 2014a) (online) http://www.mofa.go.jp/ press/release/press4e_000239.html

MOFA-Japan (Ministry of Foreign Affairs of Japan). “Tightening of Export Restrictions on Arms Dual-use Goods for Military Use to the Russian Federation and Prohibitive Measures of Issue of Securities by Designated Russian Federation Banks and their Subsidiaries", (24 September 2014b).

MOFA-Japan (Ministry of Foreign Affairs of Japan). "Measures to Freeze Assets of Those Who Are Considered to Be Directly Involved in 'Annexation' of the Autonomous Republic of Crimea and the City of Sevastopol or Destabilization of Eastern Part of Ukraine", (5 August 2014c) (online) www. mofa.go.jp/press/release/press4e_000387.html

Morgan, Clifton y Schwebach, Valerie. "Economic sanctions as an instrument of foreign policy: The role of domestic politics". International Interactions, vol. 21, issue 3 (1995), pp. 247-263.

Nikkei Asian Review. "Japan and Russia agree to work on nuclear-free North Korea”. Nikkei Asian Review, (22 March 2018) (online) https://asia.nikkei. $\mathrm{com} /$ Politics/International-relations/Japan-and-Russia-agree-to-work-onnuclear-free-North-Korea

Nippert, Matt. "Winston Peter' plans to reopen trade with Russia raises alarm from Europe". NZ Herald, (4 November 2017) (online) https://www. nzherald.co.nz/business/news/article.cfm?c_id=3\&objectid=11940045

NZ Herald. "Russia willing to start free-trade talks". NZ Herald, (29 March 2017) (online) https://www.nzherald.co.nz/business/news/article.cfm?c_ id=3\&objectid $=11827907$

NZFAT-New Zealand Foreign Affairs and Trade. "UN Security Council: Siria". New Zealand Foreign Affairs and Trade (8 October 2016) (online) 
https://www.mfat.govt.nz/en/media-and-resources/ministry-statementsand-speeches/un-security-council-syria-2/

NZP-New Zealand Parliament. "Russia - Trade Sanctions". New Zealand Parliament (8 March 2016) (online) https://www.parliament.nz/en/document 151HansQ_20160308_00000007

Ohara, Bonji. "Japan and the North Korean Dilemma: Thinking the Unthinkable". The Tokyo Foundation for Policy Research, (9 May 2017) (online) http://www.tokyofoundation.org/en/articles/2017/japan-andnorth-korea

Pardo, Ramon. "Will America lose Seoul? Redefining a critical alliance". War on the Rocks, (5 September 2018a) (online) https://warontherocks. com/2018/09/will-america-lose-seoul-redefining-a-critical-alliance/

Pardo, Ramon. "Moon's Eurasia: opening up North Korea, serving Seoul's interests". The Interpreter, (18 December 2018b) (online) https://www. lowyinstitute.org/the-interpreter/moon-eurasia-opening-north-korea-serving-seoul-interests

Patnam, Robert G. "New Zealand's Multilateralism and the Challenge of an International System in Transition". In: Echle, Christian; Rueppel, Patrick; Sarmah, Megha; Hwee, Yeo Lay (eds.). Multilateralism in a Changing World Order. Singapore: Konrad-Adenauer Stiftung, 2018, pp. 91-101.

Posen, Barry R. The Sources of Military Doctrine: France, Britain, and Germany between the World Wars. Ithaca: Cornell University Press, 1984.

Rolland, Nadège. "What the Ukraine Crisis Means for Asia". The Diplomat, (19 January 2015) (online) https://thediplomat.com/2015/01/what-theukraine-crisis-means-for-asia/

Schweller, Randall L. "Bandwagoning for Profit: Bringing the Revisionist State Back". International Security, vol. 19, issue 1 (1994), pp. 72-107.

Shagina, Maria. "Japan's Dilemma with Sanctions Policy Towards Russia: A Delicate Balancing Act”. Focus Asia. Perspective \& Analysis, Institute for Security \& Development Policy, (November 2018).

Small, Vernon. "NZ joins in 'personal sanctions' over Crimea". Stuff, (23 March 2014) (online) http://www.stuff.co.nz/national/politics/9858964/ NZ-joins-in-personal-sanctions-over-Crimea

Snyder, Scott. South Korea at the Crossroads: Autonomy and Alliance in an Era of Rival Powers. New York: Columbia University Press, 2018.

Stuff. "Russia fires back at New Zealand's UN comments on Syria". Stuff, (16 December 2016) (online) https://www.stuff.co.nz/national/politics/87667429/ russia-fires-back-at-new-zealands-un-comments-on-syria

Taehwan, Kim. "Beyond Geopolitics: South Korea's Eurasia Initiative as a New Nordpolitik". The Asan Forum, (16 February 2015) (online) http://www. 
theasanforum.org/beyond-geopolitics-south-koreas-eurasia-initiative-as-anew-nordpolitik/

Taniguchi, Tomohiko y Bob, Daniel. (2016). "The Onsen Summit: Why Japan is seeking a settlement from Russia". Sasakawa Peace Foundation USA, (14 December 2016).

The American Presidency Project. "Background Conference Call by Senior Administration Officials on Ukraine", (29 July 2014) (online) http://www. presidency.ucsb.edu/ws/index.php?pid=106693

The Asan Forum. "Country Report: Russia (May 2014)", (13 June 2014) (online) http://www.theasanforum.org/country-report-russia-may-2014/

The Japan Times. "Japan voices support for U.S.-led strikes against Syria". The Japan Times, (14 April 2018) (online) https://www.japantimes.co.jp/ news/2018/04/14/national/politics-diplomacy/japan-voices-support-u-sled-strikes-syria/

Thorhallsson, Baldur y Gunnarsson, Pétur. "Iceland's alignment with the EUUS sanctions on Russia: autonomy versus dependence". Global Affairs, vol. 3, issue 3 (2017), pp. 307-318.

Toloraya, Georgy. "A Tale of Two Peninsulas: How Will the Crimean Crisis Affect Korea?". 38North, (13 March 2014) (online) https://www.38north. org/2014/03/gtoloraya031314/

Trevett, Claire. "Exploiting Russia sanctions' bad look". NZ Herald, (17 November 2014) (online) http://www.nzherald.co.nz/business/news/article. cfm?c_id=3\&objectid=11359580

Trevett, Claire. "PM backs Winston Peters on push for free trade talks with Russia”. NZ Herald, (12 March 2018) (online) https://www.nzherald. co.nz/nz/news/article.cfm?c_id=1 \&objectid $=12011382$

Walt, Stephen M. The Origins of Alliance. Ithaca: Cornell University Press, 1987.

Waltz, Kenneth. Theory of International Politics. Reading, Massachusetts: Addison Wesley, 1979.

Wishnick, Elizabeth. "The Impact of Sino-Russian Partnership on the North Korean Crisis". In: Choo, Jaewoo; Kim, Youngjun; Lukin, Artyom and Wishnick, Elizabeth (eds.). The China-Russia Entente and the Korean Peninsula, NBR Special Report nr. 78 (2019), pp. 1-12.

Wong, Chun Han y Taylor, Rob. "U.S. Seeks Asian Backing for Sanctions on Russia". The Wall Street Journal, (30 July 2014) (online) https://www.wsj. com/articles/u-s-seeks-asian-backing-for-sanctions-on-russia-1406713409.

Young, Andrey. "NZ announces 'modest' sanctions over Crimea seizure". NZ Herald, (23 March 2014) (online) https://www.nzherald.co.nz/nz/news/article.cfm?c_id=1\&objectid=11224828 
